\title{
Axon Guidance Molecules in Vascular Patterning
}

\author{
Ralf H. Adams ${ }^{1}$ and Anne Eichmann ${ }^{2}$ \\ ${ }^{1}$ Max-Planck-Institute for Molecular Biomedicine, Department of Tissue Morphogenesis, and University of \\ Münster, Faculty of Medicine, Münster, Germany \\ ${ }^{2}$ Inserm U833, College de France, 11 Place Marcelin Berthelot, 75005 Paris, France \\ Correspondence: anne.eichmann@college-de-france.fr
}

Endothelial cells (ECs) form extensive, highly branched and hierarchically organized tubular networks in vertebrates to ensure the proper distribution of molecular and cellular cargo in the vertebrate body. The growth of this vascular system during development, tissue repair or in disease conditions involves the sprouting, migration and proliferation of endothelial cells in a process termed angiogenesis. Surprisingly, specialized ECs, so-called tip cells, which lead and guide endothelial sprouts, share many feature with another guidance structure, the axonal growth cone. Tip cells are motile, invasive and extend numerous filopodial protrusions sensing growth factors, extracellular matrix and other attractive or repulsive cues in their tissue environment. Axonal growth cones and endothelial tip cells also respond to signals belonging to the same molecular families, such as Slits and Roundabouts, Netrins and UNC5 receptors, Semaphorins, Plexins and Neuropilins, and Eph receptors and ephrin ligands. Here we summarize fundamental principles of angiogenic growth, the selection and function of tip cells and the underlying regulation by guidance cues, the Notch pathway and vascular endothelial growth factor signaling.

\section{PATTERNING OF THE VASCULAR SYSTEM}

$T_{\text {he }}^{\text {he }}$ he vasculature, like the nervous system, forms a highly branched, tree-like network that reaches into every organ of vertebrate organisms. Connectivity in the vascular system is achieved through tubules consisting of many interconnected endothelial cells (ECs). Two such networks, the lymphatic system and the blood vascular system, can be distinguished (Adams and Alitalo 2007; Carmeliet and Tessier-Lavigne 2005; Klagsbrun and Eichmann 2005). Blood vessels transport gases, nutrients, waste products, hormones and circulating cells.
The circulating blood travels from the heart through the aorta, the largest axial vessel, into a hierarchical system of arteries and smaller arterioles into distal capillary beds (Fig. 1). The latter form an elaborate network to optimize exchange between the blood stream and the surrounding tissue. Next, the blood is collected and returned by the venous branch of the circulation (Fig. 1). This involves small venules, veins and, finally, the large axial cardinal veins. Functional features, morphology and gene expression profiles of arteries and veins are distinct (Rocha and Adams 2009; Swift

Editors: Marc Tessier-Lavigne and Alex L. Kolodkin

Additional Perspectives on Neuronal Guidance available at www.cshperspectives.org

Copyright (C) 2010 Cold Spring Harbor Laboratory Press; all rights reserved; doi: 10.1101/cshperspect.a001875

Cite this article as Cold Spring Harb Perspect Biol 2010;2:a001875 
R.H. Adams and A. Eichmann

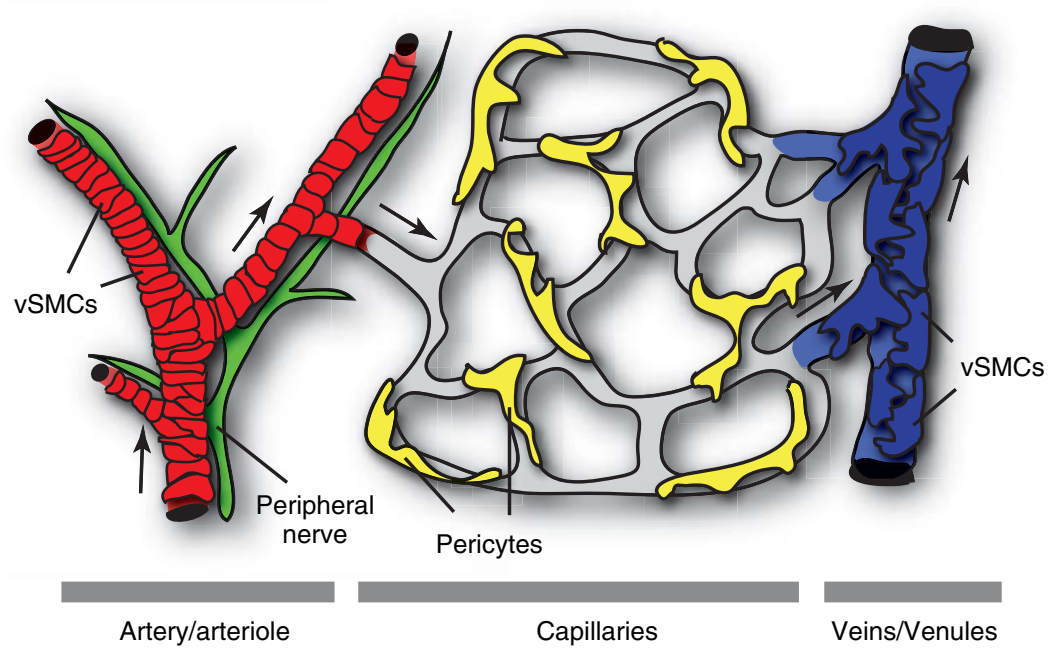

Figure 1. Schematic organization of the blood vessel network. Blood flows (arrows) through arteries and arterioles into capillaries. In the embryonic dermis, arteries develop in close association with peripheral nerves, which are a source of VEGF. Venules and veins collect the blood from capillary beds. Vascular smooth muscle cells cover arteries and vein, whereas pericytes are confined to capillaries and postcapillary venules.

and Weinstein 2009). Arteries transport blood at high pressure and speed, whereas veins form a low-pressure system, in which valves prevent backflow. In line with these hemodynamic properties, arteries are supported by one or multiple layers of specialized vascular smooth muscle cells (vSMCs), which are contractile and stabilize the vessel wall by depositing matrix and elastic fibers. Conversely, veins are enveloped by fewer vSMCs. Capillaries are covered by their own specialized support cell type, the pericytes, which are coupled to ECs by direct cell-to-cell and gap junctional contacts (Armulik et al. 2005; Bergers and Song 2005).

In contrast to the closed blood vessel network, the lymphatic vasculature functions in a unidirectional fashion. Blind-ending lymphatic capillaries (terminal lymphatics) are embedded in the organs and collect excess interstitial liquid together with extravasated cells, proteins and lipids. This watery lymph is channeled through specialized collecting lymph vessels into the larger lymphatic ducts, and, finally, into the venous circulation. Like veins, collecting lymphatics and ducts contain valves to prevent backflow and are sparsely covered by smooth muscle cells (Cueni and Detmar 2008; Karpanen and Alitalo 2008).
ECs and neurons share some fundamental challenges during the formation of their extensive networks. This may explain why both systems develop sometimes in a coordinated fashion. In peripheral tissues such as the skin, nerve fibers, and larger blood vessels, specifically arteries, align into two parallel structures (Carmeliet and Tessier-Lavigne 2005; Mukouyama et al. 2002). Genetic studies in mouse embryos suggest that peripheral nerves in the dermis provide a spatial template for the growth and differentiation of arteries. Arterial patterning and marker expression are defective in Neurogenin1/Neurogenin2 (Ngn1/ Ngn2) double knockouts lacking peripheral axons and Schwann cells in the dermis. Arteries form alongside the disorganized nerve fibers in Sema3A-deficient mice, indicating that nervederived signals directly control vascular patterning (Mukouyama et al. 2002). Cell type-specific gene ablation studies have established that arterial differentiation in the skin depends on the release of vascular endothelial growth factor A (VEGF-A) from neurons and glial cells (Mukouyama et al. 2005). VEGF-A binds and activates the receptor tyrosine kinase VEGFR2 on the EC surface and is an essential positive regulator of blood vessel growth (Ferrara 2005; 
Olsson et al. 2006). However, nerve-blood vessel alignment occurs normally in the absence of nerve-derived VEGF-A, which indicates the involvement of additional, currently unknown signals (Mukouyama et al. 2005). Functionally, aligning nerves and arteries facilitates access to oxygen and nutrients for the cells of peripheral nervous system and facilitates arterial innervation by postganglionic sympathetic fibers, which control vascular tone and participate to bloodpressure regulation (Larrivee et al. 2009).

In addition to the patterning of vessels in response to nerve-derived signals, vascular cell types can also produce guidance cues for axons. For example, arterial SMCs secrete endothelins, which are known to control blood pressure but also attract sympathetic neurons expressing the cognate receptor EDNRA. In addition, the neurotrophins NGF and NT-3, the glial-derived neurotrophic factor (GDNF) family member Artemin and its receptors Ret and GFR $\alpha 3$ control the sympathetic innervation of blood vessels (Ieda et al. 2004; Makita et al. 2008).

\section{THE ANGIOGENIC GROWTH OF BLOOD VESSELS}

New blood vessels form by different mechanisms, including de novo assembly by endothelial precursor cells or angioblasts (vasculogenesis), splitting of existing vessels (intussusception), and enlargement of the vasculature through sprouting, proliferation and remodeling processes (angiogenesis) (Adams and Alitalo 2007; Carmeliet 2000). Vasculogenesis appears to be largely confined to the formation of the first primitive vascular structures as well as the large axial vessels in the early embryo (Flamme et al. 1997). Although vasculogenic incorporation of circulating endothelial precursor cells may also occur during pathological blood vessel growth such as in cancer (Carmeliet, 2003; Rafii et al. 2002), the actual contribution of this process may be minor and is discussed controversially (Kim et al. 2009; Prater et al. 2007; Purhonen et al. 2008). Conversely, angiogenesis appears to be the main process for the formation of the vast majority of blood vessels during development, tissue repair, or disease processes.
Axon Guidance Molecules in Vascular Patterning

Small vertebrate animal models-in particular, mouse, and zebra fish — have provided first insight into fundamental aspects of angiogenic blood vessel growth. In response to insufficient local supply of oxygen (hypoxia) and perhaps other triggers, tissues up-regulate the expression of proangiogenic growth factors (Shibuya 2001). These signals activate receptors in the endothelium and lead to phenotypic changes in some ECs, which become motile, invasive, and initiate sprouting from the basal (outer) surface of the blood vessel tubules (De Smet et al. 2009; Phng and Gerhardt 2009). These sprouts extend, until they meet up with other sprouts or capillaries, and are finally converted into new blood-carrying tubules (Fig. 2). This process is highly repetitive and new sprouts are continuously formed until the proangiogenic signals are down-regulated or counterbalanced by antiangiogenic factors. The latter include certain matrix proteins, inhibitory splice variants of VEGF-A or up-regulated expression of the receptor VEGFR1/Flt1, which has weak signaling capacity but high binding affinity for VEGF (Grant and Kalluri 2005; Harper and Bates 2008; Shibuya 2001). Sprouting angiogenesis is typically accompanied by substantial EC proliferation (Fig. 2). Later steps of vascular morphogenesis involve the pruning and remodeling of the newly formed and initially dense vessel network (Baluk et al. 2004; Rocha and Adams 2009). Pericytes and vSMCs are thought to stabilize blood vessels and might promote a mature, nonangiogenic state of the vasculature (Armulik et al. 2005; Bergers and Song 2005; Betsholtz et al. 2005).

Blood vessel sprouting can be readily observed during the vascularization of the central nervous system and, in particular, in the retina. In the mouse, the retina is avascular at birth and vessels grow from the center toward the periphery following an existing network of astrocytes (Fruttiger 2007; Gerhardt et al. 2003; Provis et al. 1997). Once a primary plexus is established, sprouts dive vertically into the deeper retina and form two further vascular layers (Connolly et al. 1988; Dorrell et al. 2002). The most prominent proangiogenic factor controlling this process is VEGF-A. During the formation of 
R.H. Adams and A. Eichmann

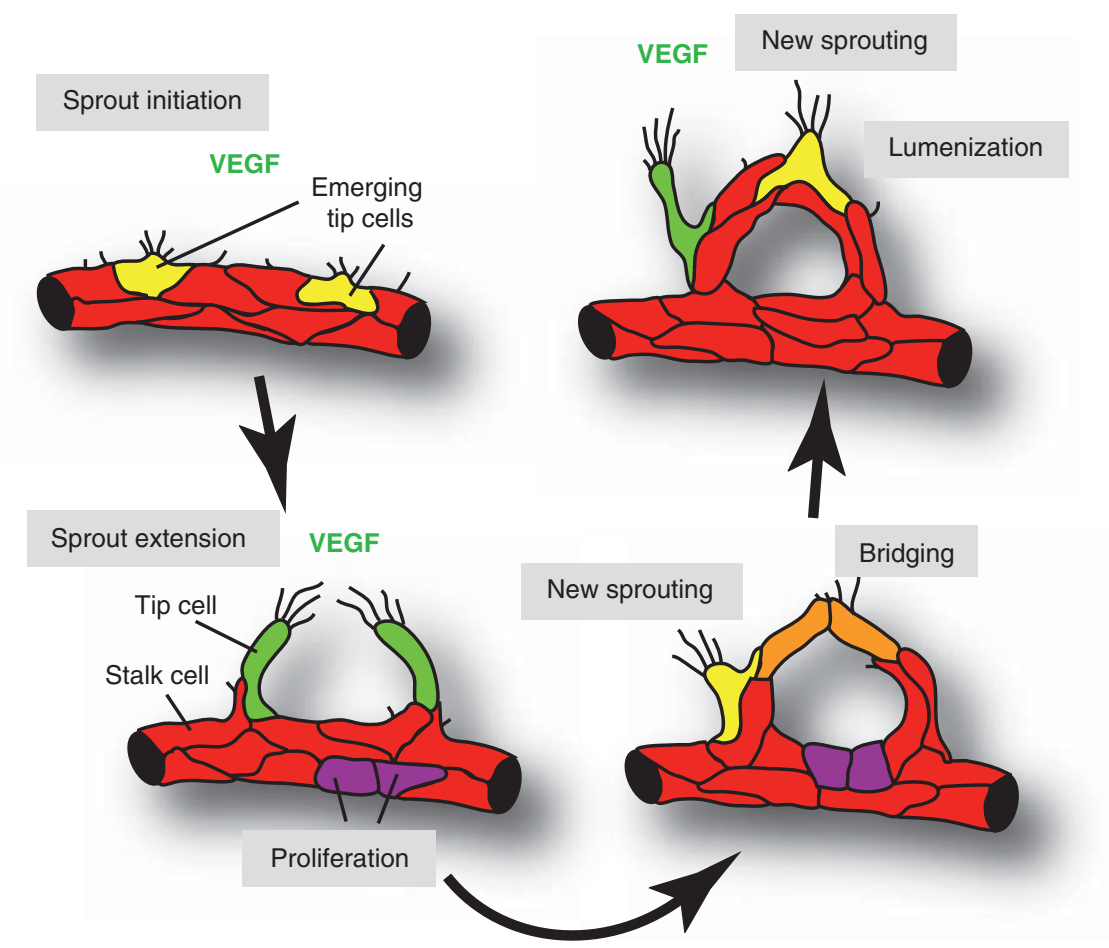

Figure 2. Angiogenic sprouting and blood vessel growth. ECs initiate sprouting in response to tissue-derived signals such as VEGF. A fraction of cells (shown in yellow and green) extends long filopodia and acquires motile and invasive behavior. These tip cells lead and guide new sprouts, whereas other ECs (shown in red) form the sprout stalk or stay behind to maintain tissue perfusion. At some point during sprout extension, tip cells will contact other tip cells or vessels to establish new connections. These cell bridges (orange) are converted into new blood-carrying vessels. Simultaneously, new sprouting is initiated at other sites (yellow and green cells) and additional ECs are generated by proliferation (purple).

the primary vascular plexus, VEGF-A is highly expressed by astrocytes in the avascular retina (Provis et al. 1997). Other members of the VEGF family, such as VEGF-C, also promote the growth of blood vessels (Tammela et al. 2008). The relevant VEGF receptors, the tyrosine kinases VEGFR2 and VEGFR3, are presented on the EC surface and, on ligand binding, trigger downstream signaling including activation of the mitogen-activated kinase pathway, phosphoinositide Kinase-3 (PI3K) and Akt, phospholipase $\mathrm{C} \gamma$, and small GTPases such as Racl (Olsson et al. 2006; Zachary 2005). How these signals or their selective activation translates into different biological responses as diverse as proliferation and differentiation, or angiogenesis and lymphangiogenesis, is not fully understood. However, some of the specificity may result from spatiotemporal expression patterns.
In development, the receptor VEGFR3/Flt4 is present on blood vessels and lymphatics, but expression becomes gradually confined to lymphatic vessels (Kaipainen et al. 1995). Neuropilins, which act as coreceptors for VEGF signaling, are also expressed in selected vascular domains. Nrp1 is present on the arterial endothelium, whereas Nrp2 is found on veins and, later in development, on lymphatic vessels (Herzog et al. 2001; Moyon et al. 2001; Mukouyama et al. 2002).

Much of the signaling controlling angiogenesis appears highly conserved among different vertebrate species, and the same components of the VEGF pathway control the growth of embryonic blood vessels in zebrafish (Covassin et al. 2006; Martyn and Schulte-Merker 2004). The transparency of the embryo, its development outside of the maternal organism, and 
high genetic and experimental accessibility make zebrafish particularly suitable for the observation of dynamic processes (Isogai et al. 2003; Lawson and Weinstein 2002).

\section{THE TIP CELL CONCEPT}

The distal end of each sprout contains a specialized EC, termed tip cell, which is motile, invasive and dynamically extends long filopodial protrusions reminiscent of axonal growth cones (Carmeliet and Tessier-Lavigne 2005; Klagsbrun and Eichmann 2005; Phng and Gerhardt 2009) (Figs. 2 and 3). Interestingly, both structures control guidance, respond to similar attractive and repulsive cues (such as Netrins, Slits, and Semaphorins), and direct the formation of new connections. Despite these parallels, the differences between tip cells and neuronal growth cones also need to be emphasized. The base of the endothelial sprout is not an axonlike extension of the tip cell, but is formed by additional ECs, termed stalk cells (Gerhardt
Axon Guidance Molecules in Vascular Patterning

et al. 2003). Few vascular sprouts do extend significantly beyond a distance of $100 \mu \mathrm{m}$ before they form new connections. To expand the vasculature over larger distances, repetitive steps of endothelial sprouting and tubulogenesis are required, which also suggests that tip cells function very transiently before they are incorporated into new vessels (Phng and Gerhardt 2009; Roca and Adams 2007). Accordingly, angiogenic stalk and tip ECs share much of their gene expression profile, although some markers are expressed selectively. Given the complex functional role of the nervous system, the selectivity of new connections has to be higher by several orders of magnitude than in the vasculature (Lowery and Van Vactor 2009; Sanes and Yamagata 2009). Unlike differentiated neurons, ECs also show a high level of proliferation and even retain significant growth potential in the adult, which can be activated in regenerative or pathological processes (Carmeliet 2003; Ferrara and Kerbel 2005). Despite these many differences, it remains remarkable that two
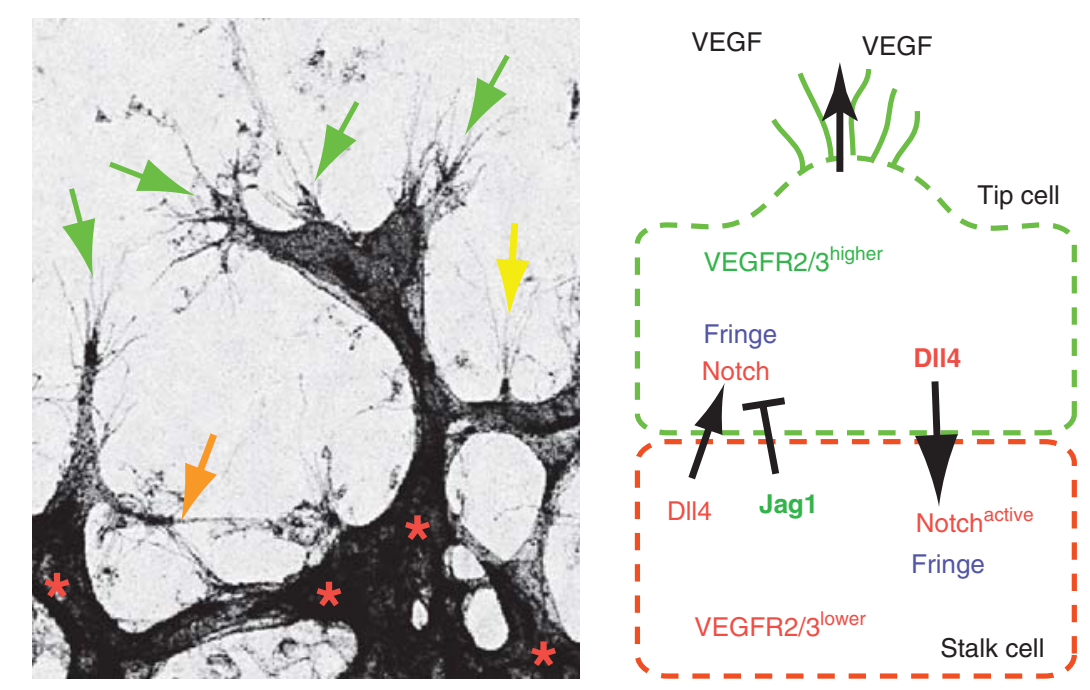

Figure 3. Regulation of tip cell formation. Left: Image of sprouting ECs in the postnatal retina. New sprouting (yellow arrow), establish sprouts with distal tip cells (green arrows), ECs forming new connections (orange arrow), and perfused vessels (red asterisks) are highlighted. Right: Schematic showing the selection of a tip cell (green) through Notch signaling. High levels of Dll4 protein in tips activates Notch and dampens VEGF signaling in an adjacent stalk EC (red). Strong expression of Jagged 1 in stalk cells antagonizes Dll4-mediated activation of Notch on neighboring tip ECs. Consequently, tip cells shown the strongest response to VEGF and grow toward the VEGF gradient. The levels of Notch signaling and the antagonistic activity of Jagged1 require Fringe-mediated glycosylation of Notch receptors. 
systems with fundamentally distinct functional roles have developed similar guidance structures to establish connectivity.

As in axon guidance, angiogenic growth involves the presentation of signals in spatial concentration gradients. In the embryonic spinal cord and the retina, the heparan sulfateanchored isoform of VEGF-A (VEGF164 in mice, VEGF165 in humans) promotes the polarization of tip cells and the directional extension of filopodia (Fig. 3) (Gerhardt et al. 2003; Ruhrberg et al. 2002). Accordingly, tip cell guidance and vascular branching are defective in mice expressing only the shorter and freely diffusible isoform VEGF120. Lack of the heparan-sulfate binding motif in VEGF120 or in proteolytically cleaved VEGF-A compromises vascular patterning but can still sustain EC proliferation (Gerhardt et al. 2003; Lee et al. 2005; Ruhrberg et al. 2002). Differential responses to VEGF might also involve Nrp1 and 2, which enhance signal transduction triggered by VEGF164 and VEGF-C, respectively (Klagsbrun et al. 2002; Neufeld et al. 2002).

During angiogenic growth, only a fraction of ECs acquires tip cell behavior and initiates sprouting, whereas other stay behind (as stalk cells) and maintain the structural and functional integrity of the vessel. The Notch pathway, which is well known for its roles in cell fate determination and differentiation processes, regulates this tip-stalk decision (Phng and Gerhardt 2009; Roca and Adams 2007; Thurston and Kitajewski 2008). Expression of the Notch ligand Delta-like 4 (Dll4) is up-regulated by VEGF and highest levels can be seen in tip cells (Benedito et al. 2009; Hellstrom et al. 2007). Dll4-mediated activation of Notch in the adjacent (stalk) ECs suppresses the tip cell phenotype in these cells, which involves down-regulation of VEGF receptor expression and presumably signaling (Fig. 3) (Benedito et al. 2009; Hellstrom et al. 2007; Siekmann and Lawson 2007; Suchting et al. 2007). Consequently, an excessive number of tip cells is formed in haploinsufficient (heterozygous) Dll4 mutant mice or when Dll4-Notch signaling is blocked (Hellstrom et al. 2007; Lobov et al. 2007; Suchting et al. 2007). This deregulated sprouting is accompanied by increased
EC proliferation, uniform expression of genes that are normally highest in tip cells, and the formation of an abnormally dense vascular network. Similarly, intersegmental sprouts fail to arrest their motile behavior and form ectopic branches when Dll4-Notch signaling is disrupted in zebrafish embryos (Leslie et al. 2007; Siekmann and Lawson 2007). In addition to Dll4, a second transmembranous Notch ligand, Jagged1, is involved in tip cell selection (Fig. 3). Inducible genetic experiments in the dermal and retinal vasculature of the mouse showed that Jagged1, unlike Dll4, is a positive regulator of angiogenesis (Benedito et al. 2009). Jagged1 opposes Dll4-Notch signaling and, accordingly, sprouting is reduced and Notch target genes are up-regulated in the absence of endothelial Jagged1. This unusual role of Jagged1 depends on sugar modifications of the Notch receptor, which enhance activation by Dll4, whereas Jagged 1 binding becomes almost nonproductive and therefore antagonizes Dll4 (Benedito et al. 2009). In the retinal vasculature, Jagged 1 and Dll4 are expressed in complementary patterns. Dll4 is highest in tips but is also present in a significant number of stalk cells, whereas Jagged 1 is almost exclusively found on stalk ECs (Benedito et al. 2009).

The role of Notch signaling as a negative regulator of sprouting is not just confined to physiological angiogenesis. The disruption of Dll4-Notch interactions in tumor models induces excessive sprouting and branching in the tumor vasculature (Li et al. 2007; NogueraTroise et al. 2006; Ridgway et al. 2006). Blood transport through this abnormal vessel network is compromised, which deprives the tumor of adequate oxygen supply and thereby decreases the growth of experimental tumors. These findings suggest that the Notch pathway might be a target for antiangiogenic cancer therapy (Li et al. 2007; Noguera-Troise et al. 2006; Ridgway et al. 2006).

\section{VASCULAR PATTERNING BY AXON GUIDANCE MOLECULES}

Axon growth cones and capillary tip cells use common signaling cues to regulate their 
guidance. Angiogenic EC express receptors for axon guidance molecules (Fig. 4), including Eph family receptor tyrosine kinases, Nrps, PlexinD1, Robo4, and UNC5B (Larrivee et al. 2009). Among those, Robo4, UNC5B, and PlexinD1 are largely confined to the vasculature, with only few expression sites in other tissues, whereas Nrps and Eph receptors show shared expression in both the vascular and the nervous system. Gene knockouts for these receptors lead to mispatterning of blood or lymphatic vessels, indicating a functional role of axon guidance receptors in vascular development. Although some receptors can be directly linked to sprouting and guidance of tip cells, others seem to have evolved novel functions in the vasculature, especially modulation of the activity of the VEGF signaling pathway, thus affecting guided vascular patterning by rendering vessels more or less responsive to VEGF.
Axon Guidance Molecules in Vascular Patterning

\section{Slits and Roundabouts}

Roundabouts (Robos) are single-pass transmembrane receptors for Slits (Brose et al. 1999; Kidd et al. 1999). The three secreted Slit proteins (Slit1-3) function as repulsive guidance cues in neural development and also play a role in kidney induction (Grieshammer et al. 2004), leukocyte migration ( $\mathrm{Wu}$ et al. 2001) and angiogenesis (Weitzman et al. 2008). Robo1-3 and Slit mutants exhibit defects in axon pathfinding at the ventral midline, and Slits function as repulsive factors that prevent axons that have crossed the midline from re-crossing (Stein and Tessier-Lavigne 2001).

Four Robos have been identified in vertebrates, with Robo4 (magic roundabout) showing selective EC expression (Huminiecki et al. 2002). Robo4 is structurally divergent and contains only two IgG-like domains and 2 FNIII

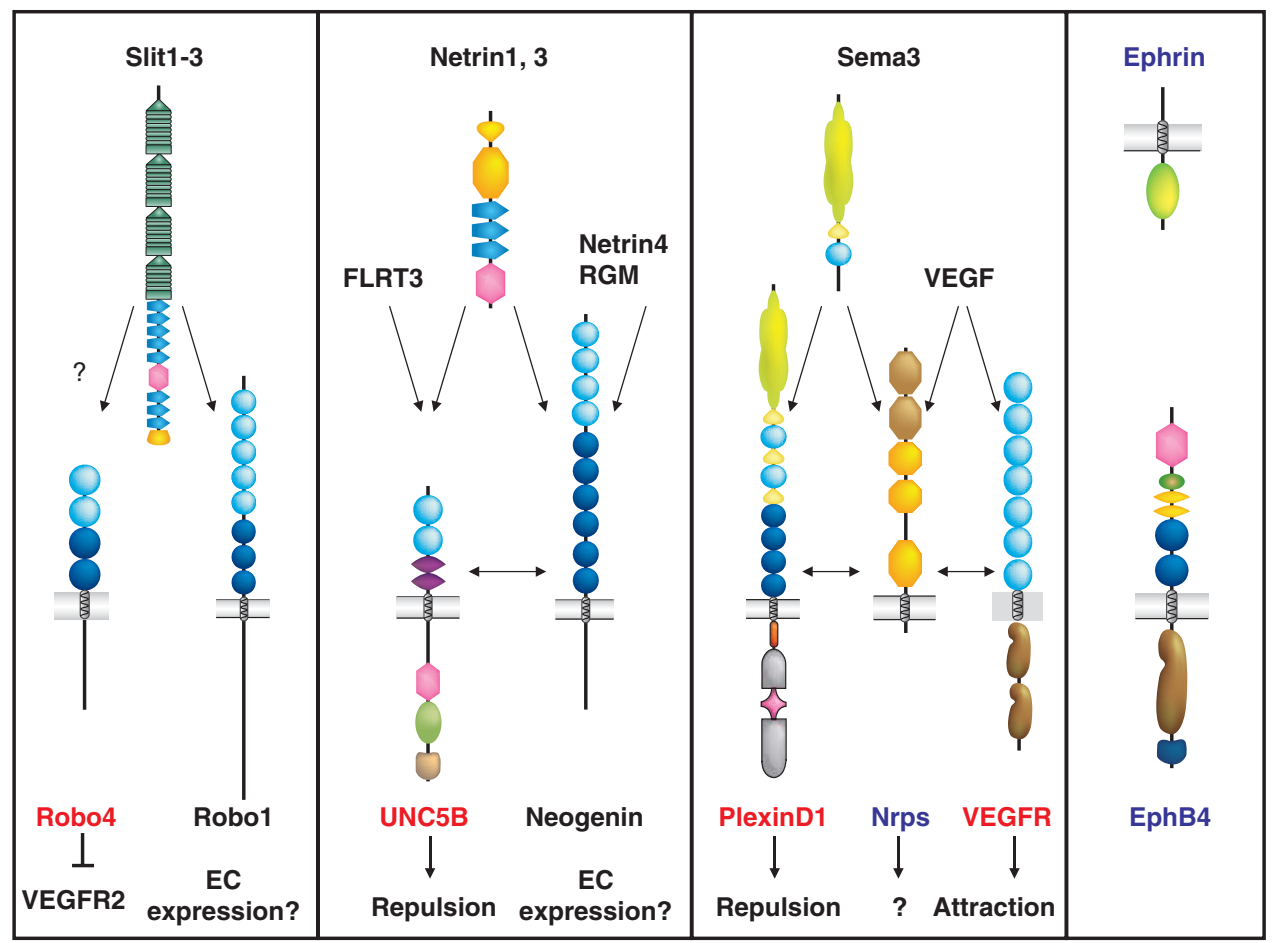

Fig. 4. Axon guidance receptor expression in ECs Schematic representation of the four families of axon guidance cues and their receptors. Predominantly endothelial-expressed receptors are labeled in red, receptors with shared expression in the nervous and the vascular system in blue and molecules with no (known) expression in the vascular system in black. Note that in each axon guidance receptor family, at least one member is expressed in the vasculature. See text for details. 
repeats in the extracellular portion and lacks the $\mathrm{CC} 1$ and CC3 motifs found in most other Robo proteins (Fig. 4). High-resolution structure of the two amino-terminal IgG-like domains of Robol has identified key Slit binding residues and a heparan sulfate/heparin binding site that strengthens the Slit-Robo1 interaction (Fukuhara et al. 2008; Hussain et al. 2006; Morlot et al. 2007). Although the amino-terminal IgG like domains of Robol and Robo4 are $42 \%$ identical, all the residues identified as Slit or heparin binding are not conserved in Robo4 and replaced by residues that are incompatible with binding Slits or heparin. These structural data suggest that Robo4 cannot bind Slits. Binding of Slit2 to Robo4 has been shown using supernatant from myc-tagged Slit2 or Slit3 transfected cells added to Robo4 expressing cells or Elisa assays (Park et al. 2003; Zhang et al. 2009a), whereas Slit binding to Robo4 has not been observed with the Biacore detection method (Suchting et al. 2005). Whether Robo4 is a bone fide receptor for Slits thus remains an open question.

Analysis of Robo4 ${ }^{-1-}$ mutant mice has suggested that Robo4 is required to maintain blood vessel integrity by counteracting VEGF-induced angiogenesis and permeability (Jones et al. 2008a). Robo $4^{-1-}$ mice are viable, but exhibit increased basal and VEGF-induced retinal vascular permeability and show hypervascularization during oxygen-induced retinopathy. Robo4 expression was preferentially observed in endothelial stalk cells, suggesting that Robo4 could prevent stalk cells from being activated by VEGF (Jones et al. 2008a). Mechanistically, increased permeability in Robo4 mutants could be rescued by treatment with the Src kinase inhibitor PP2, suggesting that Robo4 (directly or indirectly) counteracts VEGFR2 mediated Src activation, permeability and angiogenesis. Therefore, Robo4 contributes to guided vascular patterning by counteracting VEGF signaling (Jones et al. 2008a). Why this effect is only manifested during pathological ocular angiogenesis, but not during development, remains to be determined.

In zebrafish embryos, morpholino knockdown of robo4 perturbed ISV development, indicating a requirement for Robo4 in directing blood vessel growth to the correct path (Bedell et al. 2005). Angioblasts isolated from these embryos and cultured ex vivo showed more active movement when compared with angioblasts from control-MO injected fish and display lower amounts of active Cdc42 and Rac, interpreted as loss of attractive function of Robo4 in fish (Kaur et al. 2006). Mouse and zebrafish robo4 mutations therefore show quite different phenotypes, suggesting that, whereas Robo4 expression is largely conserved between mouse and fish, its function may have evolved differently.

Several studies have reported Robo1 expression in cultured ECs, indicating that Slit may affect EC migration by binding and signaling through Robo1 (Kaur et al. 2006; Sheldon et al. 2009; Zhang et al. 2009a). In situ hybridization failed to reveal vascular Robol expression (Brose et al. 1999), whereas immunostaining with an anti-Robol antibody showed vascular Robol expression (Wang et al. 2003; Zhang et al. 2009a). Conclusive demonstration of Robol function in EC is lacking, as vascular phenotypes in Robol knockout mice have not been reported. In cultured ECs, Robol can be coimmunoprecipitated with Robo4 and, when overexpressed, colocalizes with Robo4 suggesting possible Robo1-Robo4 heterodimerization. Knockdown or overexpression of Robol or Robo4 affects endothelial motility in vitro, and yeast-two hybrid screening has identified components of the downstream signaling machinery (Kaur et al. 2006; Sheldon et al. 2009). It remains however unclear if Robo1-Robo4 heterodimerization or homodimers affect migration, whether these receptors signal attraction or repulsion, and if this occurs in response to Slit ligands. An in vivo function for Slit ligands in the murine vasculature was recently reported: deletion of Slit3 leads to reduced vascular branching in the embryonic diaphragm (Zhang et al. 2009a). Whether this phenotype is also seen in other organs and in mice lacking other Slit ligands remains to be determined. It is remarkable that absence of one Slit ligand may have effects in particular organs, such as the kidney which requires Slit2 and Robo2 for 
positioning the site of kidney induction (Grieshammer et al. 2004), whereas in other systems such as the commissural axons, deletion of all three Slit ligands is required to elicit a crossing phenotype (Long et al. 2004). Elucidating the precise role of Slits and Robos in vessel patterning and guidance currently awaits full characterization of mouse mutant phenotypes and conclusive identification of a Robo4 ligand.

\section{Netrins and UNC5B}

Like Robo4, the Netrin receptor UNC5B is a vascular-specific receptor. During mouse and chick development, UNC5B is expressed in arterial ECs, sprouting capillaries and tip cells (Bouvree et al. 2008; Larrivee et al. 2009; Lu et al. 2004). UNC5B expression is restricted to subpopulations of neurons and glial cells in the retina, ear and cerebellum, and a few cell types outside the nervous system (Liu et al. 2004; Ly et al. 2005; Wang and Ramesh, 2009).

UNC5 receptors were discovered as repulsive Netrin receptors in C. elegans, Drosophila and mouse (Fig. 4) (Leonardo et al. 1997). Consistent with a repulsive function of UNC5B in the vasculature, $U n c 5 b^{-/-}$mice show ectopic filopodia in sprouting capillaries and increased capillary branching ( $\mathrm{Lu}$ et al. 2004). UNC5B activation by Netrin-1 results in filopodial retraction of endothelial tip cells and inhibits neovessel sprouting processes such as bFGFinduced matrigel plug invasion. Netrin-1 secreted from transfected cells repels porcine aortic ECs expressing UNC5B, and repulsion is lost in cells expressing a truncated form of $\mathrm{UNC} 5 \mathrm{~B}$, indicating that repulsion requires signaling through the UNC5B cytoplasmic domain (Larrivee et al. 2007). These data show that UNC5B activation prevents filopodia extension in ECs, and participates in vessel patterning by negatively regulating capillary branching. Endothelial-specific Unc5b deletion has also been shown to induce loss of placental arterioles, suggesting that UNC5B activation could promote angiogenesis in specific vascular beds (Navankasattusas et al. 2008), however it remains to be determined whether this allele represents a true null mutation.
The structure of the UNC5B cytoplasmic signaling domain has been solved (Wang et al. 2009). It includes a death domain, which has been shown to induce death of receptor expressing cells in the absence of ligand. Because the absence of a death-inducing receptor should increase cell numbers, this defect may explain the hypervascularization seen in $U n c 5 b^{-/-}$ mice. Experimental evidence in favor of a survival role for Netrin-UNC5B in the vasculature has been published (Castets et al. 2009), however, there is little EC death detectable in the normal, growing vasculature, and comparison of caspase-3+ cells in UNC5B-deficient and control mouse tissues has failed to reveal any significant differences ( $\mathrm{Lu}$ et al. 2004).

Whether UNC5B effects are mediated by endogenous Netrins remains to be determined, as no vascular defects have been described in Netrin-1-deficient mice (Salminen et al. 2000; Serafini et al. 1996). Loss-of-function genetic data for Netrin-3 and -4 are not yet available. Several novel UNC5B interaction partners were described recently. Netrin-4 was shown to act as a negative feedback regulator of angiogenesis (Lejmi et al. 2008; Nacht et al. 2009). Netrin-4 is up-regulated in ECs following longterm VEGF stimulation, and Netrin-4 inhibited VEGF-induced EC migration in vitro and pathological angiogenesis processes in vivo. Netrin-4 does not bind UNC5B directly, but was proposed to bind to Neogenin, which then recruits UNC5B to mediate the antiangiogenic activities of Netrin-4 (Lejmi et al. 2008). A second study reported interaction between the UNC5B and Neogenin ECDs in transfected 293 cells and rat embryo cortical neurons (Hata et al. 2009). Stimulation of neurons with repulsive guidance molecule (RGM) led to growth cone collapse, via RGM binding to Neogenin and UNC5B association with Larg (leukemiaacssociated guanine nucleotide exchange factor) and RhoA activation. Thus, UNC5B association with Neogenin might mediate repulsive responses in response to Netrin-4 or RGM. Another possible UNC5B binding partner, FLRT3 (fibronectin and leucine rich transmembrane protein 3 ), was isolated by expression 
library screening using the FLRT3 ECD (Karaulanov et al. 2009). These data suggest that UNC5B has numerous possible interactors/ ligands, and may even have additional, currently unknown binding partners. It remains to be determined which of these proteins are relevant for vessel patterning.

Netrins are bifunctional axon guidance cues, capable of repelling and attracting axons (Tessier-Lavigne and Goodman 1996). Netrins may also have bifunctional actions in the vasculature, as proangiogenic Netrin activities have been reported. Netrin-1 and Netrin-4 have been shown to induce proliferation and migration of ECs in vitro (Nguyen and Cai 2006; Park et al. 2004; Wilson et al. 2006). In two of these studies, none of the known Netrin receptors could be detected on the ECs used, and the mechanisms underlying Netrin's effects on these cells were not elucidated. One study reported DCC expression in ECs (Nguyen and Cai 2006), however, PCR analysis of ECs is consistently negative for DCC expression in other studies, raising doubts about potential roles of DCC as a Netrin receptor on ECs. In vivo, injection of plasmids encoding Netrin-1 or Netrin-4 accelerated neovascularization in a model of hindlimb ischemia by increasing smooth muscle cell recruitment and could reverse neuropathy and vasculopathy in a diabetic mouse model (Wilson et al. 2006). The Netrin receptor mediating these effects has not been identified, as the authors could not detect expression of any known Netrin receptors in ischemic tissue in vivo. The possibility that Netrin overexpression in ischemic tissues might target and influence the function of nonvascular inflammatory cells such as macrophages and/or monocytes remains to be examined. Netrin-1 has been shown to attenuate hypoxia-induced inflammation and polymorphonuclear neutrophil influx in vivo, an effect linked to its binding the AdenosineA2B receptor (Rosenberger et al. 2009). Netrins may therefore affect postischemic revascularization via modification of the inflammatory response or directly by binding to an as yet unidentified receptor on ECs.
Semaphorins, Plexins, and Neuropilins

Semaphorins are a large family of cell-associated and secreted proteins that share a common Sema domain (Yazdani and Terman, 2006). Membrane-associated Semaphorins bind to Plexins, whereas secreted class III Semaphorins (Sema3A to G) bind to Nrps, which do not signal themselves but function as coreceptors for Plexin signaling (Bagri et al. 2009). An exception to this rule is Sema3E, which directly binds PlexinD1 and does not interact directly with Nrps (Gu et al. 2005). PlexinD1, one of the nine mammalian plexins, is prominently expressed in developing blood vessel ECs (van der Zwaag et al. 2002). In mouse embryos, Plxnd1 knockout results in neonatal lethality, defects of the vasculature, heart outflow tract and skeleton (Gitler et al. 2004). Endothelial Plxnd1 knockouts recapitulate these defects (Zhang et al. 2009b), demonstrating the importance of endothelial PlexinD1 for vascular patterning. Sema3e and Plxnd1 mouse mutant embryos exhibit highly similar patterning defects in the trunk vessels ( $\mathrm{Gu}$ et al. 2005). Double-mutant mice deficient in Nrp2 and in the Nrp1 Sema3 binding site show normal segmental blood vessel patterns, indicating that the Sema3e and Plxnd 1 phenotypes develop independently of Nrps. Blood vessels avoid chick embryo somites that overexpress Sema3E, suggesting that the protein mediates EC repulsion. Thus, Sema3E directly signals through PlexinD1 to restrict blood vessel growth in mice, at least in the trunk segments ( $\mathrm{Gu}$ et al. 2005). In zebra fish, loss-of-function mutations in the plxnD1 gene are responsible for the out-ofbounds $(o b d)$ mutation (Torres-Vazquez et al. 2004). Obd fish show normal artery-vein specification and EC proliferation, but exhibit exuberant ISV branching. The ligand requirement appears to differ between mice and fish, as fish sema3e mutants show delayed rather than exuberant ISV formation (Lamont et al. 2009). These data suggest that in addition to Sema3E, PlexinD1 may also participate in receptor complexes for other Semaphorin ligands. In support of this idea, Plxnd1 ${ }^{-/-}$mutants exhibit more 
severe perinatal lethality as compared with Sema3e $e^{-/-}$mice, and PlexinD1 in complex with Nrp1 or Nrp2 can bind Sema3A, Sema3C and/or Sema4A in vitro (Gitler et al. 2004; Toyofuku et al. 2007).

Neuropilins (Nrp1, Nrp2) are single-pass transmembrane proteins with a large ECD and a short cytoplasmic domain that presents a PDZ binding site (Bagri et al. 2009) (Fig. 4). Nrps bind to structurally and functionally unrelated ligands, the best studied of which are secreted class III Semaphorins and VEGF family members (Bagri et al. 2009; Ellis, 2006; GluzmanPoltorak et al. 2000; Neufeld and Kessler 2008; Soker et al. 1998). Initial studies suggested that Semaphorins and VEGF family members could compete for binding to Nrps. However, crystal structures show that VEGF and Semaphorins bind to different parts of the Nrp ECD (Appleton et al. 2007). Sema3A-deficient mice and mutants expressing an Nrp1 variant that cannot bind Sema3A show normal vascular development, arguing that Sema3A is not required for angiogenesis in the mouse (Gu et al. 2003). In contrast, Sema3A, but not VEGF164, is required for axon patterning of limb nerves (Vieira et al. 2007a, b). These data suggest that Nrp1 contributes to both neuronal and vascular patterning by preferentially relaying Sema3A signals in peripheral axons and VEGF164 signals in blood vessels. Furthermore, Semaphorins and VEGF induce Nrp1 endocytosis through different pathways; VEGF binding induces clathrin-mediated endocytosis, whereas Sema3C induces lipid raft-dependent endocytosis (Salikhova et al. 2008). Therefore, each of the two endocytic pathways used by Nrp1 could contribute to its signaling specificity by coupling it to a different set of downstream effectors, depending on which ligand it binds.

The principle function of Nrps appears to be the regulation of cell motility in both the nervous and the vascular system. Whereas the guidance functions Nrps exert in response to Semaphorins in the nervous system are mainly repulsive and mediate growth cone collapse (Chen et al. 2000), they appear to be attractive in the vascular system and mediate tip cell extension and guided vessel sprouting in response to VEGF family growth factors.
Axon Guidance Molecules in Vascular Patterning

The absence of a functional Nrp1 receptor results in embryonic lethality because of impaired heart development and defective endothelial migration, leading to vessel enlargement at the expense of vessel branching and sprouting defects (Gerhardt et al. 2004; Jones et al. 2008b; Kawasaki et al. 1999). Global and endothelialspecific Nrp1 knockouts also exhibit defective arterial differentiation (Mukouyama et al. 2005). Thus, Nrp1 function is critical for normal vascular development and arterial differentiation. In contrast to Nrp1 mutants, arterial-venous differentiation is normal in Nrp2 knockouts. Instead, homozygous Nrp2 mutants show reduced lymphatic vessel sprouting during development (Yuan et al. 2002).

Blocking antibodies selectively disrupting Semaphorin or VEGF binding to Nrps were recently generated (Caunt et al. 2008; Pan et al. 2007). Anti-Nrp1A antibody blocks Sema3A binding and anti-Nrp1B blocks VEGF binding to Nrp1, though both prevent Nrp1 complex formation with VEGFR2. Anti-Nrp2B blocks VEGF-165 and VEGF-C binding to Nrp2 and prevents complex formation of Nrp2 with VEGFR2 and VEGFR3. In vivo administration of anti-Nrp-1B to cultured mouse embryos recapitulates the phenotypes seen in Nrpl knockouts (Jones et al. 2008b), whereas treatment with anti-NRP2B recapitulates defective lymphatic sprouting seen in Nrp2 mutants (Xu Y. et al. 2010). Nrp2 genetically interacts with VEGFR3, and not VEGFR2, indicating that Nrp2 partners with VEGFR3 to modulate lymphatic vessel sprouting (Xu Y. et al. in press). Treatment of tumor bearing mice results in reduced tumor angiogenesis (Nrp1) and lymphangiogenesis (Nrp2), respectively (Caunt et al. 2008; Pan et al. 2007). These experiments indicate that blocking of Nrp receptors may be a useful strategy for reducing tumor angiogenesis and metastasis in a clinical setting and reveal critical, yet nonoverlapping function for Nrp receptors in blood and lymphatic vessels.

\section{Ephrins and Eph receptors}

Eph receptor tyrosine kinases (RTKs), a large family of transmembrane proteins with a single 
cytoplasmic kinase domain, and their binding partners, the ephrins, regulate morphogenesis in many different tissues and species. Ephrins are cell surface proteins that are either attached via a glycosylphosphatidylinisotol (GPI) anchor (ephrin-A subclass) or a transmembrane region (ephrin-B ligands) (Fig. 4). Based on binding preference and sequence homology, Ephs have also been subdivided into EphA and EphB subclasses (Kullander and Klein 2002; Pasquale, 2005; Poliakov et al. 2004). In addition to their role as Eph-activating ligands (termed "forward signaling"), ephrins also have receptor-like signal transduction capability, so-called "reverse signaling." For B-class ephrins, this process involves the recruitment of adapter proteins to phosphotyrosine residues in the cytoplasmic domain and a carboxyterminal PDZ-binding motif, whereas ephrin-A ligands activate Src family kinases in response to Eph binding (Kullander and Klein 2002; Pasquale, 2005; Poliakov et al. 2004).

Several Eph and ephrin molecules are prominently expressed in the vascular system. For example, ephrin-A1 and EphA2 were detected in the vasculature of xenografted tumors (Ogawa et al. 2000). Both molecules are also expressed in tumor cells and have been linked to VEGF expression and endothelial cell migration (Brantley-Sieders et al. 2006; Hunter et al. 2006). Of the B-class ligands and receptors, ephrin-B2 and EphB4 have attracted the most attention because they selectively mark the endothelium of arteries and veins, respectively (Adams et al. 1999; Gerety et al. 1999; Wang et al. 1998). Because the ECs of established arteries and veins would normally not contact each other, it has proven difficult to link these complementary expression patterns to functional roles. However, a recent study has revealed that zebrafish embryos initially form only a single axial vessel, termed common precursor vessel, which subsequently segregates into a distinct dorsal aorta and cardinal vein (Herbert et al. 2009). This process involves many of the known regulators of vascular morphogenesis, such as Notch and VEGF signaling. In addition, ephrin-B2 (encoded by the gene efnb2a in zebrafish) and EphB4 control the sorting and segregation of cells with distinct arterial-venous fates. Ephrin-B2-expressing cells have limited ability to migrate ventrally out of the common precursor vessel, remain behind and thereby constitute the dorsal aorta. Conversely, EphB4-positive ECs preferentially contribute to the cardinal vein (Herbert et al. 2009). Although we currently lack formal proof for a similar segregation process in mammals, there are some hints in favor of such a mechanism. The calibers of the embryonic axial vessels in the mouse are reciprocally balanced by Notch, ephrin-B2, and EphB4, which could be explained by the selective migration of ECs, and conspicuous connections occur transiently in the anterior part of these two major axial vessels (Kim et al. 2008).

Targeted inactivation of the genes encoding ephrin-B2 (Efnb2) and EphB4 (Ephb4) in mice has highlighted that this receptor-ligand pair is essential for the angiogenic growth of the embryonic vasculature (Adams et al. 1999; Gerety and Anderson 2002; Gerety et al. 1999; Wang et al. 1998). Both ephrin-B2 and EphB4 are also expressed in the growing lymphatic vasculature. The characterization of ephrin-B2 knockin mice has shown that angiogenic sprouting of lymphatic ECs requires ephrin-B2 reverse signaling through the carboxy-terminal PDZ motif. In contrast, mutants lacking the conserved cytoplasmic phosphotyrosine are surprisingly devoid of overt vascular defects (Makinen et al. 2005). Ephrin-B2 is also expressed pericytes and vSMCs, and plays important roles in mural cell recruitment and vessel wall assembly (Foo et al. 2006; Gale et al. 2001; Salvucci et al. 2009; Shin et al. 2001). In culture, ephrin-B2 deficient vascular smooth muscle cells are defective in spreading, focal adhesion formation, and show increased but unpolarized motility (Foo et al. 2006). Surprisingly, some of these defects appear to be cell-contactindependent, suggesting a cell-autonomous role for ephrin-B2.

In the adult, ephrin-B2 expression is up-regulated during physiological and pathological neoangiogenesis (Gale et al. 2001; Shin et al. 2001). Indicating a proangiogenic role of ephrin-B2 in pathological settings, expression 
of EphB4 in tumor cells enhances blood vessel growth through interactions with endothelial ephrin-B2 (Noren et al. 2006). In contrast, EphB4 and reverse signaling by ephrin-B2 can also act as a negative regulator of branching angiogenesis by promoting circumferential growth of blood vessels and suppressing endothelial sprouting (Erber et al. 2006). Soluble fusion proteins containing the EphB4 ECD (sEphB4) reduce tumor growth and vascularization by antagonizing endogenous receptorligand interactions (Kertesz et al. 2006; Martiny-Baron et al. 2004). These data suggest that targeting ephrin-B2 and/or EphB4 might be therapeutically beneficial in the context of cancer.

Despite the evidence above, the precise mechanistic role of ephrin-B2 and EphB4 in ECs of the growing vasculature remains unclear. Stimulation with soluble, recombinant ephrin-B or EphB proteins indicates that both reverse and forward signaling can promote sprouting of cultured ECs (Adams et al. 1999; Palmer et al. 2002). EphB4 activation enhances EC migration and proliferation, which involves downstream signaling by PI3-kinase and the serin/threonine-specific kinase Akt/PKB (Maekawa et al. 2003; Steinle et al. 2002). However, in other experiments, forward EphB4 signaling inhibits EC migration, adhesion and proliferation by suppressing the activation of the small GTPase Ras and mitogen-activated protein (MAP) kinase (Fuller et al. 2003; Hamada et al. 2003; Kim et al. 2002). Eph-ephrin interactions also affect extracellular matrix adhesion and cell migration by modulating integrin activity (Huynh-Do et al. 2002; Meyer et al. 2005; Miao et al. 2005). However, the exact role of Eph/ephrin molecules in angiogenic sprouting and the in vivo relevance of specific signaling cascades triggered by forward or reverse signaling remain unknown.

Overall, the morphological similarities between endothelial tip cells and axonal growth cones highlight how two very different systems with completely distinct function have found analogous solutions for the formation of complex and extensively branched networks. One of the most striking common features is the
Axon Guidance Molecules in Vascular Patterning

utilization of certain molecular pathways-like Ephs and ephrins, Semaphorins, Plexins and Neuropilins, Netrins and UNC5B, or Robo4for the regulation of patterning and growth processes. Some of these molecular regulators may also help to coordinate the growth of nerve fibers and blood vessels in developing or regenerating tissues. The latter may have significant therapeutic implications and could be used to efficiently organize complex patterning processes in tissue repair processes. Likewise, future work will have to explore whether certain disease conditions involve or are caused by defects in this neurovascular interface. Although most of the current studies focus on developmental processes, we also know very little about putative interdependent relationships between nerves and blood vessels in tissue homeostasis. These and other interesting questions call for further research on this exciting topic.

\section{REFERENCES}

Adams RH, Alitalo K. 2007. Molecular regulation of angiogenesis and lymphangiogenesis. Nat Rev Mol Cell Biol 8: 464-478.

Adams RH, Wilkinson GA, Weiss C, Diella F, Gale NW, Deutsch U, Risau W, Klein R. 1999. Roles of ephrinB ligands and $\mathrm{EphB}$ receptors in cardiovascular development: demarcation of arterial/venous domains, vascular morphogenesis, and sprouting angiogenesis. Genes Dev 13: 295-306.

Appleton BA, Wu P, Maloney J, Yin J, Liang WC, Stawicki S, Mortara K, Bowman KK, Elliott JM, Desmarais W, et al. 2007. Structural studies of neuropilin/antibody complexes provide insights into semaphorin and VEGF binding. EMBO J 26: 4902-4912.

Armulik A, Abramsson A, Betsholtz C. 2005. Endothelial/ pericyte interactions. Circ Res 97: 512-523.

Bagri A, Tessier-Lavigne M, Watts RJ. 2009. Neuropilins in tumor biology. Clin Cancer Res 15: 1860-1864.

Baluk P, Lee CG, Link H, Ator E, Haskell A, Elias JA, McDonald DM. 2004. Regulated angiogenesis and vascular regression in mice overexpressing vascular endothelial growth factor in airways. Am J Pathol 165: 1071-1085.

Bedell VM, Yeo SY, Park KW, Chung J, Seth P, Shivalingappa V, Zhao J, Obara T, Sukhatme VP, Drummond IA, et al. 2005. roundabout4 is essential for angiogenesis in vivo. Proc Natl Acad Sci U S A 102: 6373-6378.

Benedito R, Roca C, Sorensen I, Adams S, Gossler A, Fruttiger M, Adams RH. 2009. The notch ligands Dll4 and Jagged1 have opposing effects on angiogenesis. Cell 137: $1124-1135$.

Bergers G, Song S. 2005. The role of pericytes in blood-vessel formation and maintenance. Neuro Oncol 7: 452-464. 
R.H. Adams and A. Eichmann

Betsholtz C, Lindblom P, Gerhardt H. 2005. Role of pericytes in vascular morphogenesis. EXS, 115-125.

Bouvree K, Larrivee B, Lv X, Yuan L, DeLafarge B, Freitas C, Mathivet T, Breant C, Tessier-Lavigne M, Bikfalvi A, et al. 2008. Netrin-1 inhibits sprouting angiogenesis in developing avian embryos. Dev Biol 318: 172-183.

Brantley-Sieders DM, Fang WB, Hwang Y, Hicks D, Chen J. 2006. Ephrin-A1 facilitates mammary tumor metastasis through an angiogenesis-dependent mechanism mediated by EphA receptor and vascular endothelial growth factor in mice. Cancer Res 66: 10315-10324.

Brose K, Bland KS, Wang KH, Arnott D, Henzel W, Goodman CS, Tessier-Lavigne M, Kidd T. 1999. Slit proteins bind Robo receptors and have an evolutionarily conserved role in repulsive axon guidance. Cell 96: 795-806.

Carmeliet P. 2000. Mechanisms of angiogenesis and arteriogenesis. Nat Med 6: 389-395.

Carmeliet P. 2003. Angiogenesis in health and disease. Nat Med 9: 653-660.

Carmeliet P, Tessier-Lavigne M. 2005. Common mechanisms of nerve and blood vessel wiring. Nature 436: 193-200.

Castets M, Coissieux MM, Delloye-Bourgeois C, Bernard L, Delcros JG, Bernet A, Laudet V, Mehlen P. 2009. Inhibition of endothelial cell apoptosis by netrin-1 during angiogenesis. Dev Cell 16: 614-620.

Caunt M, Mak J, Liang WC, Stawicki S, Pan Q, Tong RK, Kowalski J, Ho C, Reslan HB, Ross J, et al. 2008. Blocking neuropilin-2 function inhibits tumor cell metastasis. Cancer Cell 13: 331-342.

Chen H, Bagri A, Zupicich JA, Zou Y, Stoeckli E, Pleasure SJ, Lowenstein DH, Skarnes WC, Chedotal A, TessierLavigne M. 2000. Neuropilin-2 regulates the development of selective cranial and sensory nerves and hippocampal mossy fiber projections. Neuron 25: 43-56.

Connolly SE, Hores TA, Smith LE, D'Amore PA. 1988. Characterization of vascular development in the mouse retina. Microvasc Res 36: 275-290.

Covassin LD, Villefranc JA, Kacergis MC, Weinstein BM, Lawson ND. 2006. Distinct genetic interactions between multiple Vegf receptors are required for development of different blood vessel types in zebrafish. Proc Natl Acad Sci U S A 103: 6554-6559.

Cueni LN, Detmar M. 2008. The lymphatic system in health and disease. Lymphat Res Biol 6: 109-122.

De Smet F, Segura I, De Bock K, Hohensinner PJ, Carmeliet P. 2009. Mechanisms of vessel branching: filopodia on endothelial tip cells lead the way. Arterioscler Thromb Vasc Biol 29: 639-649.

Dorrell MI, Aguilar E, Friedlander M. 2002. Retinal vascular development is mediated by endothelial filopodia, a preexisting astrocytic template and specific R-cadherin adhesion. Invest Ophthalmol Vis Sci 43: 3500-3510.

Ellis LM. 2006. The role of neuropilins in cancer. Mol Cancer Ther 5: 1099-1107.

Erber R, Eichelsbacher U, Powajbo V, Korn T, Djonov V, Lin J, Hammes HP, Grobholz R, Ullrich A, Vajkoczy P. 2006. EphB4 controls blood vascular morphogenesis during postnatal angiogenesis. Embo J 25: 628-641.

Ferrara N. 2005. The role of VEGF in the regulation of physiological and pathological angiogenesis. EXS, 209-231.
Ferrara N, Kerbel RS. 2005. Angiogenesis as a therapeutic target. Nature 438: 967-974.

Flamme I, Frolich T, Risau W. 1997. Molecular mechanisms of vasculogenesis and embryonic angiogenesis. J Cell Physiol 173: 206-210.

Foo SS, Turner CJ, Adams S, Compagni A, Aubyn D, Kogata N, Lindblom P, Shani M, Zicha D, Adams RH. 2006. Ephrin-B2 controls cell motility and adhesion during blood-vessel-wall assembly. Cell 124: 161-173.

Fruttiger M. 2007. Development of the retinal vasculature. Angiogenesis 10: 77-88.

Fukuhara N, Howitt JA, Hussain SA, Hohenester E. 2008. Structural and functional analysis of slit and heparin binding to immunoglobulin-like domains 1 and 2 of Drosophila Robo. J Biol Chem 283: 16226-16234.

Fuller T, Korff T, Kilian A, Dandekar G, Augustin HG. 2003. Forward EphB4 signaling in endothelial cells controls cellular repulsion and segregation from ephrinB2 positive cells. J Cell Sci 116: 2461-2470.

Gale NW, Baluk P, Pan L, Kwan M, Holash J, DeChiara TM, McDonald DM, Yancopoulos GD. 2001. Ephrin-B2 selectively marks arterial vessels and neovascularization sites in the adult, with expression in both endothelial and smooth-muscle cells. Dev Biol 230: 151-160.

Gerety SS, Anderson DJ. 2002. Cardiovascular ephrinB2 function is essential for embryonic angiogenesis. Development 129: 1397-1410.

Gerety SS, Wang HU, Chen ZF, Anderson DJ. 1999. Symmetrical mutant phenotypes of the receptor EphB4 and its specific transmembrane ligand ephrin-B2 in cardiovascular development. Mol Cell 4: 403-414.

Gerhardt H, Golding M, Fruttiger M, Ruhrberg C, Lundkvist A, Abramsson A, Jeltsch M, Mitchell C, Alitalo K, Shima D, et al. 2003. VEGF guides angiogenic sprouting utilizing endothelial tip cell filopodia. J Cell Biol 161: 1163-1177.

Gerhardt H, Ruhrberg C, Abramsson A, Fujisawa H, Shima D, Betsholtz C. 2004 . Neuropilin-1 is required for endothelial tip cell guidance in the developing central nervous system. Dev Dyn 231: 503-509.

Gitler AD, Lu MM, Epstein JA. 2004. PlexinD1 and semaphorin signaling are required in endothelial cells for cardiovascular development. Dev Cell 7: 107-116.

Gluzman-Poltorak Z, Cohen T, Herzog Y, Neufeld G. 2000. Neuropilin-2 is a receptor for the vascular endothelial growth factor (VEGF) forms VEGF-145 and VEGF-165 [corrected]. J Biol Chem 275: 18040-18045.

Grant MA, Kalluri R. 2005. Structural basis for the functions of endogenous angiogenesis inhibitors. Cold Spring Harb Symp Quant Biol 70: 399-410.

Grieshammer U, Le M, Plump AS, Wang F, Tessier-Lavigne M, Martin GR. 2004. SLIT2-mediated ROBO2 signaling restricts kidney induction to a single site. Dev Cell 6: 709-717.

Gu C, Rodriguez ER, Reimert DV, Shu T, Fritzsch B, Richards LJ, Kolodkin AL, Ginty DD. 2003. Neuropilin-1 conveys semaphorin and VEGF signaling during neural and cardiovascular development. Dev Cell 5: 45-57.

Gu C, Yoshida Y, Livet J, Reimert DV, Mann F, Merte J, Henderson CE, Jessell TM, Kolodkin AL, Ginty DD. 2005. 
Semaphorin 3E and plexin-D1 control vascular pattern independently of neuropilins. Science 307: 265-268.

Hamada K, Oike Y, Ito Y, Maekawa H, Miyata K, Shimomura T, Suda T. 2003. Distinct roles of ephrin-B2 forward and EphB4 reverse signaling in endothelial cells. Arterioscler Thromb Vasc Biol 23: 190-197.

Harper SJ, Bates DO. 2008. VEGF-A splicing: the key to antiangiogenic therapeutics? Nat Rev Cancer 8: 880-887.

Hata K, Kaibuchi K, Inagaki S, Yamashita T. 2009. Unc5B associates with LARG to mediate the action of repulsive guidance molecule. J Cell Biol 184: 737-750.

Hellstrom M, Phng LK, Hofmann JJ, Wallgard E, Coultas L, Lindblom P, Alva J, Nilsson AK, Karlsson L, Gaiano N, et al. 2007. Dll4 signalling through Notch1 regulates formation of tip cells during angiogenesis. Nature 445: $776-780$.

Herbert SP, Huisken J, Kim TN, Feldman ME, Houseman BT, Wang RA, Shokat KM, Stainier DY. 2009. Arterial-venous segregation by selective cell sprouting: an alternative mode of blood vessel formation. Science 326: 294-298.

Herzog Y, Kalcheim C, Kahane N, Reshef R, Neufeld G. 2001 Differential expression of neuropilin-1 and neuropilin-2 in arteries and veins. Mech Dev 109: 115-119.

Huminiecki L, Gorn M, Suchting S, Poulsom R, Bicknell R. 2002. Magic roundabout is a new member of the roundabout receptor family that is endothelial specific and expressed at sites of active angiogenesis. Genomics 79: 547-552.

Hunter SG, Zhuang G, Brantley-Sieders D, Swat W, Cowan CW, Chen J. 2006. Essential role of Vav family guanine nucleotide exchange factors in EphA receptor-mediated angiogenesis. Mol Cell Biol 26: 4830-4842.

Hussain SA, Piper M, Fukuhara N, Strochlic L, Cho G, Howitt JA, Ahmed Y, Powell AK, Turnbull JE, Holt CE, et al. 2006. A molecular mechanism for the heparan sulfate dependence of slit-robo signaling. J Biol Chem 281: 39693-39698.

Huynh-Do U, Vindis C, Liu H, Cerretti DP, McGrew JT, Enriquez M, Chen J, Daniel TO. 2002. Ephrin-B1 transduces signals to activate integrin-mediated migration, attachment and angiogenesis. J Cell Sci 115: 3073-3081.

Ieda M, Fukuda K, Hisaka Y, Kimura K, Kawaguchi H, Fujita J, Shimoda K, Takeshita E, Okano H, Kurihara Y, et al. 2004. Endothelin-1 regulates cardiac sympathetic innervation in the rodent heart by controlling nerve growth factor expression. J Clin Invest 113: 876-884.

Isogai S, Lawson ND, Torrealday S, Horiguchi M, Weinstein BM. 2003. Angiogenic network formation in the developing vertebrate trunk. Development 130: 5281-5290.

Jones CA, London NR, Chen H, Park KW, Sauvaget D, Stockton RA, Wythe JD, Suh W, Larrieu-Lahargue F, Mukouyama YS, et al. 2008a. Robo4 stabilizes the vascular network by inhibiting pathologic angiogenesis and endothelial hyperpermeability. Nat Med 14: 448-453.

Jones EA, Yuan L, Breant C, Watts RJ, Eichmann A. 2008b. Separating genetic and hemodynamic defects in neuropilin 1 knockout embryos. Development 135: 2479-2488.

Kaipainen A, Korhonen J, Mustonen T, van Hinsbergh VW, Fang GH, Dumont D, Breitman M, Alitalo K. 1995. Expression of the fms-like tyrosine kinase 4 gene becomes
Axon Guidance Molecules in Vascular Patterning

restricted to lymphatic endothelium during development. Proc Natl Acad Sci U S A 92: 3566-3570.

Karaulanov E, Bottcher RT, Stannek P, Wu W, Rau M, Ogata S, Cho KW, Niehrs C. 2009. Unc5B interacts with FLRT3 and Rndl to modulate cell adhesion in Xenopus embryos. PLoS One 4: pe5742.

Karpanen T, Alitalo K. 2008. Molecular biology and pathology of lymphangiogenesis. Annu Rev Pathol 3: 367-397.

Kaur S, Castellone MD, Bedell VM, Konar M, Gutkind JS, Ramchandran R. 2006. Robo4 signaling in endothelial cells implies attraction guidance mechanisms. J Biol Chem 281: 11347-11356.

Kawasaki T, Kitsukawa T, Bekku Y, Matsuda Y, Sanbo M, Yagi T, Fujisawa H. 1999. A requirement for neuropilin-1 in embryonic vessel formation. Development 126: $4895-$ 4902.

Kertesz N, Krasnoperov V, Reddy R, Leshanski L, Kumar SR, Zozulya S, Gill PS. 2006. The soluble extracellular domain of EphB4 (sEphB4) antagonizes EphB4-EphrinB2 interaction, modulates angiogenesis, and inhibits tumor growth. Blood 107: 2330-2338.

Kidd T, Bland KS, Goodman CS. 1999. Slit is the midline repellent for the robo receptor in Drosophila. Cell 96: 785-794.

Kim YH, Hu H, Guevara-Gallardo S, Lam MT, Fong SY, Wang RA. 2008. Artery and vein size is balanced by Notch and ephrin B2/EphB4 during angiogenesis. Development 135: 3755-3764.

Kim SJ, Kim JS, Papadopoulos J, Wook Kim S, Maya M, Zhang F, He J, Fan D, Langley R, Fidler IJ. 2009. Circulating monocytes expressing CD31: implications for acute and chronic angiogenesis. Am J Pathol 174: 1972-1980.

Kim I, Ryu YS, Kwak HJ, Ahn SY, Oh JL, Yancopoulos GD, Gale NW, Koh GY. 2002. EphB ligand, ephrinB2, suppresses the VEGF- and angiopoietin 1-induced Ras/ mitogen-activated protein kinase pathway in venous endothelial cells. FASEB J 16: 1126-1128.

Klagsbrun M, Eichmann A. 2005. A role for axon guidance receptors and ligands in blood vessel development and tumor angiogenesis. Cytokine Growth Factor Rev 16: 535-548.

Klagsbrun M, Takashima S, Mamluk R. 2002. The role of neuropilin in vascular and tumor biology. Adv Exp Med Biol 515: 33-48

Kullander K, Klein R. 2002. Mechanisms and functions of Eph and ephrin signalling. Nat Rev Mol Cell Biol 3: 475-486.

Lamont RE, Lamont EJ, Childs SJ. 2009. Antagonistic interactions among Plexins regulate the timing of intersegmental vessel formation. Dev Biol 331: 199-209.

Larrivee B, Freitas C, Suchting S, Brunet I, Eichmann A. 2009. Guidance of vascular development: lessons from the nervous system. Circ Res 104: 428-441.

Larrivee B, Freitas C, Trombe M, Lv X, Delafarge B, Yuan L, Bouvree K, Breant C, Del Toro R, Brechot N, et al. 2007. Activation of the UNC5B receptor by Netrin-1 inhibits sprouting angiogenesis. Genes Dev 21: 2433-2447.

Lawson ND, Weinstein BM. 2002. In vivo imaging of embryonic vascular development using transgenic zebrafish. Dev Biol 248: 307-318. 
R.H. Adams and A. Eichmann

Lee S, Jilani SM, Nikolova GV, Carpizo D, Iruela-Arispe ML. 2005. Processing of VEGF-A by matrix metalloproteinases regulates bioavailability and vascular patterning in tumors. J Cell Biol 169: 681-691.

Lejmi E, Leconte L, Pedron-Mazoyer S, Ropert S, Raoul W Lavalette S, Bouras I, Feron JG, Maitre-Boube M, Assayag F, et al. 2008. Netrin-4 inhibits angiogenesis via binding to neogenin and recruitment of Unc5B. Proc Natl Acad Sci U S A 105: 12491-12496.

Leonardo ED, Hinck L, Masu M, Keino-Masu K, Ackerman SL, Tessier-Lavigne M. 1997. Vertebrate homologues of C. elegans UNC-5 are candidate netrin receptors. Nature 386: $833-838$.

Leslie JD, Ariza-McNaughton L, Bermange AL, McAdow R, Johnson SL, Lewis J. 2007. Endothelial signalling by the Notch ligand Delta-like 4 restricts angiogenesis. Development 134: 839-844.

Li JL, Sainson RC, Shi W, Leek R, Harrington LS, Preusser M, Biswas S, Turley H, Heikamp E, Hainfellner JA, et al. 2007. Delta-like 4 Notch ligand regulates tumor angiogenesis, improves tumor vascular function, and promotes tumor growth in vivo. Cancer Res 67: 1124411253.

Liu Y, Stein E, Oliver T, Li Y, Brunken WJ, Koch M, TessierLavigne M, Hogan BL. 2004. Novel role for Netrins in regulating epithelial behavior during lung branching morphogenesis. Curr Biol 14: 897-905.

Lobov IB, Renard RA, Papadopoulos N, Gale NW, Thurston G, Yancopoulos GD, Wiegand SJ. 2007. $\delta$-like ligand 4 (Dll4) is induced by VEGF as a negative regulator of angiogenic sprouting. Proc Natl Acad Sci U S A 104: 3219-3224.

Long H, Sabatier C, Ma L, Plump A, Yuan W, Ornitz DM, Tamada A, Murakami F, Goodman CS, Tessier-Lavigne M. 2004. Conserved roles for Slit and Robo proteins in midline commissural axon guidance. Neuron 42: 213-223.

Lowery LA, Van Vactor D. 2009. The trip of the tip: understanding the growth cone machinery. Nat Rev Mol Cell Biol 10: 332-343.

Lu X, Le Noble F, Yuan L, Jiang Q, De Lafarge B, Sugiyama D, Breant C, Claes F, De Smet F, Thomas JL, et al. 2004. The netrin receptor UNC5B mediates guidance events controlling morphogenesis of the vascular system. Nature 432: $179-186$.

Ly NP, Komatsuzaki K, Fraser IP, Tseng AA, Prodhan P, Moore KJ, Kinane TB. 2005. Netrin-1 inhibits leukocyte migration in vitro and in vivo. Proc Natl Acad Sci U S A 102: 14729-14734.

Maekawa H, Oike Y, Kanda S, Ito Y, Yamada Y, Kurihara H, Nagai R, Suda T. 2003. Ephrin-B2 induces migration of endothelial cells through the phosphatidylinositol-3 kinase pathway and promotes angiogenesis in adult vasculature. Arterioscler Thromb Vasc Biol 23: 2008-2014.

Makinen T, Adams RH, Bailey J, Lu Q, Ziemiecki A, Alitalo K, Klein R, Wilkinson GA. 2005. PDZ interaction site in ephrinB2 is required for the remodeling of lymphatic vasculature. Genes Dev 19: 397-410.

Makita T, Sucov HM, Gariepy CE, Yanagisawa M, Ginty DD. 2008. Endothelins are vascular-derived axonal guidance cues for developing sympathetic neurons. Nature 452: $759-763$.
Martiny-Baron G, Korff T, Schaffner F, Esser N, Eggstein S, Marme D, Augustin HG. 2004. Inhibition of tumor growth and angiogenesis by soluble EphB4. Neoplasia 6: 248-257.

Martyn U, Schulte-Merker S. 2004. Zebrafish neuropilins are differentially expressed and interact with vascular endothelial growth factor during embryonic vascular development. Dev Dyn 231: 33-42.

Meyer S, Hafner C, Guba M, Flegel S, Geissler EK, Becker B, Koehl GE, Orso E, Landthaler M, Vogt T. 2005. Ephrin-B2 overexpression enhances integrin-mediated ECM-attachment and migration of B16 melanoma cells. Int J Oncol 27: 1197-1206.

Miao H, Strebhardt K, Pasquale EB, Shen TL, Guan JL, Wang B. 2005. Inhibition of integrin-mediated cell adhesion but not directional cell migration requires catalytic activity of EphB3 receptor tyrosine kinase. Role of Rho family small GTPases. J Biol Chem 280: 923-932.

Morlot C, Thielens NM, Ravelli RB, Hemrika W, Romijn RA, Gros P, Cusack S, McCarthy AA. 2007. Structura insights into the Slit-Robo complex. Proc Natl Acad Sci US A 104: 14923-14928.

Moyon D, Pardanaud L, Yuan L, Breant C, Eichmann A. 2001. Plasticity of endothelial cells during arterial-venous differentiation in the avian embryo. Development 128: 3359-3370.

Mukouyama YS, Gerber HP, Ferrara N, Gu C, Anderson DJ. 2005. Peripheral nerve-derived VEGF promotes arterial differentiation via neuropilin 1-mediated positive feedback. Development 132: 941-952.

Mukouyama YS, Shin D, Britsch S, Taniguchi M, Anderson DJ. 2002. Sensory nerves determine the pattern of arterial differentiation and blood vessel branching in the skin. Cell 109: 693-705.

Nacht M, St Martin TB, Byrne A, Klinger KW, Teicher BA, Madden SL, Jiang Y. 2009. Netrin-4 regulates angiogenic responses and tumor cell growth. Exp Cell Res 315: 784-794.

Navankasattusas S, Whitehead KJ, Suli A, Sorensen LK, Lim AH, Zhao J, Park KW, Wythe JD, Thomas KR, Chien CB et al. 2008. The netrin receptor UNC5B promotes angiogenesis in specific vascular beds. Development 135: 659-667.

Neufeld G, Kessler O. 2008. The semaphorins: versatile regulators of tumour progression and tumour angiogenesis. Nat Rev Cancer 8: 632-645.

Neufeld G, Kessler O, Herzog Y. 2002. The interaction of Neuropilin-1 and Neuropilin-2 with tyrosine-kinase receptors for VEGF. Adv Exp Med Biol 515: 81-90.

Nguyen A, Cai H. 2006. Netrin-1 induces angiogenesis via a DCC-dependent ERK1/2-eNOS feed-forward mechanism. Proc Natl Acad Sci U S A 103: 6530-6535.

Noguera-Troise I, Daly C, Papadopoulos NJ, Coetzee S, Boland P, Gale NW, Lin HC, Yancopoulos GD, Thurston G. 2006. Blockade of Dll4 inhibits tumour growth by promoting non-productive angiogenesis. Nature 444: $1032-1037$.

Noren NK, Foos G, Hauser CA, Pasquale EB. 2006. The EphB4 receptor suppresses breast cancer cell tumorigenicity through an Abl-Crk pathway. Nat Cell Biol 8: 815-825. 
Ogawa K, Pasqualini R, Lindberg RA, Kain R, Freeman AL, Pasquale EB. 2000. The ephrin-Al ligand and its receptor, EphA2, are expressed during tumor neovascularization. Oncogene 19: 6043-6052.

Olsson AK, Dimberg A, Kreuger J, Claesson-Welsh L. 2006 VEGF receptor signalling - in control of vascular function. Nat Rev Mol Cell Biol 7: 359-371.

Palmer A, Zimmer M, Erdmann KS, Eulenburg V, Porthin A, Heumann R, Deutsch U, Klein R. 2002. EphrinB phosphorylation and reverse signaling: regulation by Src kinases and PTP-BL phosphatase. Mol Cell 9: 725-737.

Pan Q, Chanthery Y, Liang WC, Stawicki S, Mak J, Rathore N, Tong RK, Kowalski J, Yee SF, Pacheco G, et al. 2007. Blocking neuropilin-1 function has an additive effect with anti-VEGF to inhibit tumor growth. Cancer Cell 11: $53-67$.

Park KW, Crouse D, Lee M, Karnik SK, Sorensen LK, Murphy KJ, Kuo CJ, Li DY. 2004. The axonal attractant Netrin-1 is an angiogenic factor. Proc Natl Acad Sci US A 101: 16210-16215.

Park KW, Morrison CM, Sorensen LK, Jones CA, Rao Y, Chien CB, Wu JY, Urness LD, Li DY. 2003. Robo4 is a vascular-specific receptor that inhibits endothelial migration. Dev Biol 261: 251-267.

Pasquale EB. 2005. Eph receptor signalling casts a wide net on cell behaviour. Nat Rev Mol Cell Biol 6: 462-475.

Phng LK, Gerhardt H. 2009. Angiogenesis: a team effort coordinated by notch. Dev Cell 16: 196-208.

Poliakov A, Cotrina M, Wilkinson DG. 2004. Diverse roles of eph receptors and ephrins in the regulation of cell migration and tissue assembly. Dev Cell 7: 465-480.

Prater DN, Case J, Ingram DA, Yoder MC. 2007. Working hypothesis to redefine endothelial progenitor cells. Leukemia 21: 1141-1149.

Provis JM, Leech J, Diaz CM, Penfold PL, Stone J, Keshet E. 1997. Development of the human retinal vasculature: cellular relations and VEGF expression. Exp Eye Res 65: 555-568.

Purhonen S, Palm J, Rossi D, Kaskenpaa N, Rajantie I, YlaHerttuala S, Alitalo K, Weissman IL, Salven P. 2008. Bone marrow-derived circulating endothelial precursors do not contribute to vascular endothelium and are not needed for tumor growth. Proc Natl Acad Sci U S A 105: $6620-6625$

Rafii S, Lyden D, Benezra R, Hattori K, Heissig B. 2002. Vascular and haematopoietic stem cells: novel targets for anti-angiogenesis therapy? Nat Rev Cancer 2: 826-835.

Ridgway J, Zhang G, Wu Y, Stawicki S, Liang WC, Chanthery Y, Kowalski J, Watts RJ, Callahan C, Kasman I, et al. 2006. Inhibition of Dll4 signalling inhibits tumour growth by deregulating angiogenesis. Nature 444: 1083-1087.

Roca C, Adams RH. 2007. Regulation of vascular morphogenesis by Notch signaling. Genes Dev 21: 2511-2524.

Rocha SF, Adams RH. 2009. Molecular differentiation and specialization of vascular beds. Angiogenesis 12: 139-147.

Rosenberger P, Schwab JM, Mirakaj V, Masekowsky E, Mager A, Morote-Garcia JC, Unertl K, Eltzschig HK. 2009. Hypoxia-inducible factor-dependent induction of netrin-1 dampens inflammation caused by hypoxia. Nat Immunol 10: 195-202.
Axon Guidance Molecules in Vascular Patterning

Ruhrberg C, Gerhardt H, Golding M, Watson R, Ioannidou S, Fujisawa H, Betsholtz C, Shima DT. 2002. Spatially restricted patterning cues provided by heparin-binding VEGF-A control blood vessel branching morphogenesis. Genes Dev 16: 2684-2698.

Salikhova A, Wang L, Lanahan AA, Liu M, Simons M, Leenders WP, Mukhopadhyay D, Horowitz A. 2008. Vascular endothelial growth factor and semaphorin induce neuropilin-1 endocytosis via separate pathways. Circ Res 103: e71-79.

Salminen M, Meyer BI, Bober E, Gruss P. 2000. Netrin 1 is required for semicircular canal formation in the mouse inner ear. Development 127: 13-22.

Salvucci O, Maric D, Economopoulou M, Sakakibara S, Merlin S, Follenzi A, Tosato G. 2009. EphrinB reverse signaling contributes to endothelial and mural cell assembly into vascular structures. Blood 114: 1707-1716.

Sanes JR, Yamagata M. 2009. Many paths to synaptic specificity. Annu Rev Cell Dev Biol 25: 161-195.

Serafini T, Colamarino SA, Leonardo ED, Wang H, Beddington R, Skarnes WC, Tessier-Lavigne M. 1996. Netrin-1 is required for commissural axon guidance in the developing vertebrate nervous system. Cell 87: 1001-1014.

Sheldon H, Andre M, Legg JA, Heal P, Herbert JM, Sainson R, Sharma AS, Kitajewski JK, Heath VL, Bicknell R. 2009. Active involvement of Robol and Robo4 in filopodia formation and endothelial cell motility mediated via WASP and other actin nucleation-promoting factors. FASEB $J$ 23: $513-522$

Shibuya M. 2001. Structure and dual function of vascular endothelial growth factor receptor-1 (Flt-1). Int J Biochem Cell Biol 33: 409-420.

Shin D, Garcia-Cardena G, Hayashi S, Gerety S, Asahara T, Stavrakis G, Isner J, Folkman J, Gimbrone MA Jr, Anderson DJ. 2001. Expression of ephrinB2 identifies a stable genetic difference between arterial and venous vascular smooth muscle as well as endothelial cells, and marks subsets of microvessels at sites of adult neovascularization. Dev Biol 230: 139-150.

Siekmann AF, Lawson ND. 2007. Notch signalling limits angiogenic cell behaviour in developing zebrafish arteries. Nature 445: 781-784.

Soker S, Takashima S, Miao HQ, Neufeld G, Klagsbrun M. 1998. Neuropilin-1 is expressed by endothelial and tumor cells as an isoform-specific receptor for vascular endothelial growth factor. Cell 92: 735-745.

Stein E, Tessier-Lavigne M. 2001. Hierarchical organization of guidance receptors: silencing of netrin attraction by slit through a Robo/DCC receptor complex. Science 291: 1928-1938.

Steinle JJ, Meininger CJ, Forough R, Wu G, Wu MH, Granger HJ. 2002. Eph B4 receptor signaling mediates endothelial cell migration and proliferation via the phosphatidylinositol 3-kinase pathway. J Biol Chem 277: 43830-43835.

Suchting S, Freitas C, le Noble F, Benedito R, Breant C, Duarte A, Eichmann A. 2007. The Notch ligand Deltalike 4 negatively regulates endothelial tip cell formation and vessel branching. Proc Natl Acad Sci U S A 104: $3225-3230$. 
R.H. Adams and A. Eichmann

Suchting S, Heal P, Tahtis K, Stewart LM, Bicknell R. 2005. Soluble Robo4 receptor inhibits in vivo angiogenesis and endothelial cell migration. FASEB J 19: 121-123.

Swift MR, Weinstein BM. 2009. Arterial-venous specification during development. Circ Res 104: 576-588.

Tammela T, Zarkada G, Wallgard E, Murtomaki A, Suchting S, Wirzenius M, Waltari M, Hellstrom M, Schomber T, Peltonen R, et al. 2008. Blocking VEGFR-3 suppresses angiogenic sprouting and vascular network formation. Nature 454: 656-660.

Tessier-Lavigne M, Goodman CS. 1996. The molecular biology of axon guidance. Science 274: 1123-1133.

Thurston G, Kitajewski J. 2008. VEGF and Delta-Notch: interacting signalling pathways in tumour angiogenesis. Br J Cancer 99: 1204-1209.

Torres-Vazquez J, Gitler AD, Fraser SD, Berk JD, Van NP, Fishman MC, Childs S, Epstein JA, Weinstein BM. 2004. Semaphorin-plexin signaling guides patterning of the developing vasculature. Dev Cell 7: 117-123.

Toyofuku T, Yabuki M, Kamei J, Kamei M, Makino N, Kumanogoh A, Hori M. 2007. Semaphorin-4A, an activator for T-cell-mediated immunity, suppresses angiogenesis via Plexin-D1. EMBO J 26: 1373-1384.

van der Zwaag B, Hellemons AJ, Leenders WP, Burbach JP, Brunner HG, Padberg GW, Van Bokhoven H. 2002. PLEXIN-D1, a novel plexin family member, is expressed in vascular endothelium and the central nervous system during mouse embryogenesis. Dev Dyn 225: 336-343.

Vieira JM, Schwarz Q, Ruhrberg C. 2007a. Role of the neuropilin ligands VEGF164 and SEMA3A in neuronal and vascular patterning in the mouse. Novartis Found Symp 283: 230-235; discussion 235-241.

Vieira JM, Schwarz Q, Ruhrberg C. 2007b. Selective requirements for NRP1 ligands during neurovascular patterning. Development 134: 1833-1843.

Wang W, Ramesh G. 2009. Segment-specific expression of netrin-1 receptors in normal and ischemic mouse kidney. Am J Nephrol 30: 186-193.

Wang HU, Chen ZF, Anderson DJ. 1998. Molecular distinction and angiogenic interaction between embryonic arteries and veins revealed by ephrin-B2 and its receptor Eph-B4. Cell 93: 741-753.

Wang R, Wei Z, Jin H, Wu H, Yu C, Wen W, Chan LN, Wen Z, Zhang M. 2009. Autoinhibition of UNC5b revealed by the cytoplasmic domain structure of the receptor. $\mathrm{Mol}$ Cell 33: 692-703.

Wang B, Xiao Y, Ding BB, Zhang N, Yuan X, Gui L, Qian KX, Duan S, Chen Z, Rao Y, et al. 2003. Induction of tumor angiogenesis by Slit-Robo signaling and inhibition of cancer growth by blocking Robo activity. Cancer Cell 4: $19-29$.

Weitzman M, Bayley EB, Naik UP. 2008. Robo4: a guidance receptor that regulates angiogenesis. Cell Adh Migr 2: $220-222$.

Wilson BD, Ii M, Park KW, Suli A, Sorensen LK, LarrieuLahargue F, Urness LD, Suh W, Asai J, Kock GA, et al. 2006. Netrins promote developmental and therapeutic angiogenesis. Science 313: 640-644.

Wu JY, Feng L, Park HT, Havlioglu N, Wen L, Tang H, Bacon KB, Jiang Z, Zhang X, Rao Y. 2001. The neuronal repellent Slit inhibits leukocyte chemotaxis induced by chemotactic factors. Nature 410: 948-952.

Xu Y, Yuan L, Mak J, Pardanaud L, Caunt M, Kasman I, Larrivée B, Suchting S, det Toro R, Medvinsky A, et al. 2010. Neuropilin-2 mediates VEGF-C induced lymphatic sprouting together with VEGFR3. J Cell Biol 188: $115-130$.

Yuan L, Moyon D, Pardanaud L, Breant C, Karkkainen MJ, Alitalo K, Eichmann A. 2002. Abnormal lymphatic vessel development in neuropilin 2 mutant mice. Development 129: 4797-4806.

Zachary I. 2005. Signal transduction in angiogenesis. EXS, 267-300.

Zhang B, Dietrich UM, Geng JG, Bicknell R, Esko JD, Wang L. 2009a. Repulsive axon guidance molecule Slit3 is a novel angiogenic factor. Blood.

Zhang Y, Singh MK, Degenhardt KR, Lu MM, Bennett J, Yoshida Y, Epstein JA. 2009b. Tie2Cre-mediated inactivation of plexinD1 results in congenital heart, vascular and skeletal defects. Dev Biol 325: 82-93. 


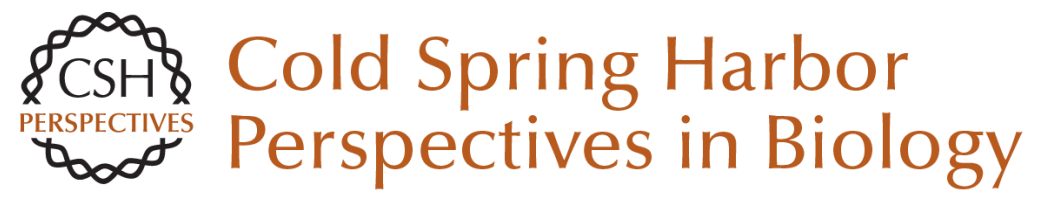

\section{Axon Guidance Molecules in Vascular Patterning}

Ralf H. Adams and Anne Eichmann

Cold Spring Harb Perspect Biol 2010; doi: 10.1101/cshperspect.a001875 originally published online March 31, 2010

\section{Subject Collection Neuronal Guidance}

Mechanisms and Molecules of Neuronal Wiring: A Primer

Alex L. Kolodkin and Marc Tessier-Lavigne

Guidance Molecules in Axon Pruning and Cell

Death

Pierre Vanderhaeghen and Hwai-Jong Cheng

Initiating and Growing an Axon

F. Polleux and William Snider

Navigating Intermediate Targets: The Nervous System Midline

Barry J. Dickson and Yimin Zou

Cellular Strategies of Axonal Pathfinding

Jonathan Raper and Carol Mason

Guidance Molecules in Axon Regeneration

Roman J. Giger, Edmund R. Hollis II and Mark H. Tuszynski

Signaling from Axon Guidance Receptors Greg J. Bashaw and Rüdiger Klein

Visual Map Development: Bidirectional Signaling, Bifunctional Guidance Molecules, and Competition

David A. Feldheim and Dennis D. M. O'Leary
Wiring the Brain: The Biology of Neuronal Guidance

Alain Chédotal and Linda J. Richards

Guidance Molecules in Synapse Formation and

Plasticity Kang Shen and Christopher W. Cowan

The Growth Cone Cytoskeleton in Axon

Outgrowth and Guidance

Erik W. Dent, Stephanie L. Gupton and Frank B. Gertler

Topographic Mapping--The Olfactory System Takeshi Imai, Hitoshi Sakano and Leslie B. Vosshall

Self-avoidance and Tiling: Mechanisms of

Dendrite and Axon Spacing Wesley B. Grueber and Alvaro Sagasti

Trafficking Guidance Receptors Bettina Winckler and Ira Mellman

Axon Guidance Molecules in Vascular Patterning Ralf H. Adams and Anne Eichmann

Human Genetic Disorders of Axon Guidance Elizabeth C. Engle

For additional articles in this collection, see http://cshperspectives.cshlp.org/cgi/collection/

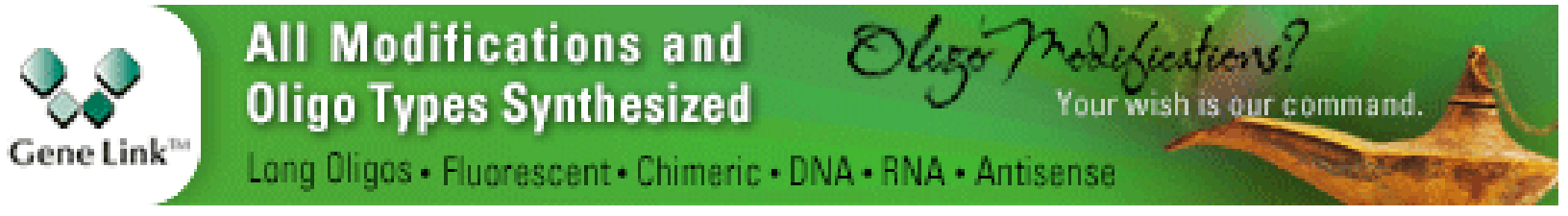

Copyright @ 2010 Cold Spring Harbor Laboratory Press; all rights reserved 